DOI: https://doi.org/10.15407/techned2018.06 $\leq \underline{009}$

\title{
COMPUTER STUDY OF DAMAGED CABLES WITH ELECTRIC FIELD DISTRIBUTION OUTSIDE THEM
}

Journal

Publisher

ISSN

Issue

Pages
Tekhnichna elektrodynamika

Institute of Electrodynamics National Academy of Science of Ukraine 1607-7970 (print), 2218-1903 (online)

No 6, 2018 (November/December)

$9-13$

\section{Author}

\section{Kucheriava I.M.}

Institute of Electrodynamics National Academy of Sciences of Ukraine,

pr. Peremohy, 56, Kyiv, 03057, Ukraine,

e-mail: rb.irinan@gmail.com

\begin{abstract}
The electric field distribution inside the polyethylene insulation of power cable and outside the cable with typical degradation of its jacket, metallic shield and a large part of the insulation is studied by computer modeling. The two- and three-dimensional problems are solved numerically to determine electric field strength. As shown, the interface between the main insulation and the defects is a weak site which is liable to further failure and deterioration of cable in service. For the damages under consideration the electric field is spread outside the cable at small distance, not more than 1.5 times larger than cable radius as the average. Refere nces 11, figures 5 .
\end{abstract}


Key words: cross-linked polyethylene insulation, cable damages (damages of metallic shield / neutral, outer semiconducting layer, main insulation), electric filed outside the cable, two- and three-dimensional computer modeling.

Received: 28.02 .2018

Accepted: 15.05 .2018

Published: 23.10 .2018

\section{References}

1. Abdolall K., Halldorson G. L., Green D. Condition assessment and failure modes of solid dielectric cables in perspective. IEEE Trans. on Power Delivery. 2002. Vol. 17. No 1. Pp. 18-24.

2. Abdolall K., Stephens M., Rao A., Kung D. Condition assessment of the underground distribution feeders of BC Hydro. 2010 PES-ICC Meeting, March 21-24, 2010. 38 p. URL: http ://www.pesicc.org/iccWebSite/subcommittees/C/C26/Presentations/2010Spring/C18-Spring-Co nditionAssessmentofUndergroundDistributionFeedersofBC.pdf

3. Borodyanskii Yu.M. Damages of cable with cross-linked polyethylene insulation. Kabel-news .2009. No 9. Pp. 60-61.

4. Kucheriava I.M. Defects of conductor screen and their influence on electric field distribution in polyethylene insulation of power cable. Tekhnichna Elektrodynamika. 2018. No 1. Pp. 17-22. 5. Hernandez-Mejia J.C. Characterization of real power cable defects by diagnostic measurements. Thesis for the Degree Doctor of Philosophy. Georgia Institute of Technology, 2008. $292 \mathrm{p}$.

6. Hernandez-Mejia J.C., Perkel J. Metallic shield assessment. Chapter 11. University System of Georgia, Institute of Technology, National Electric Energy Testing, Research and Application Center. Cable Diagnostic Focused Initiative. Georgia Tech Research Corporation, February 2016. $45 \mathrm{p}$. 
7. Isus D., Martinez J.D., Madina V., Santa Coloma P. Corrosion behaviour of submarine power cables in seawater environment. $8^{\text {th }}$ Internat. Conf. on Insulated Power Cables. Jicable'11.

19-23 June 2011, Versailles, France. Paper A.6.6. 4 p.

8. Kucheriava I.M. Power cable defects and their influence on electric field distribution in polyethylene insulation. Tekhnichna Elektrodynamika. 2017. No 2. Pp. 19-24.

9. Buchholz V. Finding the root cause of power cable failures. URL: http://www.electricenergy online.com/show article.php?article $=186$

10. Kucheriava I.M. Electric field enhancement in polyethylene cable insulation with defects. $T e$ khnichna Elektrodynamika

. 2018. No 2. Pp. 11-16.

11. Comsol multiphysics modeling and simulation software. URL: http://www.comsol.com/

$\underline{\text { PDF }}$ 